\title{
TRANSPARENCY IN CLINICAL TRIALS
}

Pavlov ChS ${ }^{1}$, Varganova $\mathrm{DL}^{2} \otimes$, Svistunov $A A^{1}$, Gluud $\mathrm{C}^{3}$

${ }^{1}$ Sechenov First Moscow State Medical University (Sechenov University), Moscow, Russia

${ }^{2}$ Ulyanovsk State Clinical Hospital, Ulyanovsk, Russia

${ }^{3}$ Clinical Trial Unit, Coppenhagen, Denmark

In the age of information technology development, healthcare professionals around the world have the opportunity to simultaneously access advanced scientific developments, modern achievements, and the results of new clinical trials. The clinical guidelines of the international medical communities are based on the results of meta-analyses of clinical trial data. As new medical challenges emerge, clinical trial data are reviewed and re-analyzed. Unfortunately, to date, the results of not all studies are made public, or are presented selectively, indicating the positive effects of a particular technology (intervention), which makes it difficult to critically evaluate the results of work and makes the task of assessing the true effectiveness of the intervention more difficult. The problem of transparency of research data with the preservation of personal data of participants remains relevant for decades. This article is focused on possible ways of solving this problem and the analysis of the current situation in the world.

Keywords: clinical trials, transparency, openness.

Author contribution: Pavlov ChS — original concept, manuscript writing and editing; Varganova DL — literature analysis, manuscript writing; Svistunov AA, Gluud C - part in the concept and structure of the paper, manuscript editing.

$\triangle$ Correspondence should be addressed: Daria L. Varganova 3-Internatsionala, 7, Ulyanovsk, 432063, Russia; datich@ya.ru

Received: 02.05.2021 Accepted: 25.05.2021 Published online: 30.06.2021

DOI: $10.24075 /$ medet.2021.014

\section{ТРАНСПАРЕНТНОСТЬ В КЛИНИЧЕСКИХ ИССЛЕДОВАНИЯХ}

ч. С. Павлов ${ }^{1}$, Д. Л. Варганова ${ }^{\square}$, А. А. Свистунов ${ }^{1}$, Кристиан Глууд $^{3}$

1 Первый Московский государственный медицинский университет им. И. М. Сеченова, Москва, Россия

2Ульяновская областная клиническая больница, Ульяновск, Россия

${ }^{3}$ Центр Клинических Исследований, Коппенгаген, Дания

В век развития информационных технологий специалисты здравоохранения по всему миру получили возможность одновременного доступа кпередовым научным разработкам, современным достижениям, результатам новых клинических исследований. Клинические рекомендации международных медицинских сообществ построены на результатах мета-анализов данных клинических исследований. По мере появления новых медицинских задач проводится пересмотр данных клинических исследований и их повторный анализ. К сожалению, на сегодняшний день результаты не всех исследований предаются огласке, либо представляются выборочно, указывая положительные эффекты той или иной технологии (вмешательства), что затрудняет критическую оценку результатов работы и делает задачу оценки истинной эффективности вмешательства более сложной. Проблема открытости (транспарентности) данных исследований с сохранением персональных данных участников остается актуальной на протяжении десятков лет. Данная статья посвящена возможным путям решения данной проблемы и анализу сложившейся в мире ситуации.

Ключевые слова: клинические исследования, транспарентность, прозрачность.

Вклад авторов: Павлов Ч. С.- автор идеи, написание и редактирование текста; Варганова Д. Л.- изучение литературы, написание текста; Свистунов А. А., Кристиан Глууд — вклад в концепцию и структуру статьи, редактирование.

$\triangle$ Для корреспонденции: Дарья Леонидовна Варганова

ул. 3-Интернационала, д. 7, г. Ульяновск, 432063, Россия; datich@уa.ru

Поступила: 02.05.2021 Статья принята к печати: 25.05.2021 Опубликована онлайн: 30.06.2021

DOI: 10.24075/medet.2021.014

\section{PREFACE}

In today's world, during the era of evidence-based medicine, the patient-management tactics is selected in accordance with the clinical guidelines, based upon the data of systematic reviews and meta-analyses, which compile the results of randomized clinical trials [1]. Clinical trials, systematic reviews and meta-analyses enable us to assess true benefits and harm of certain intervention, medication or technology. With the high methodological quality of the study, adherence to all scientific principles, as well as the opportunity of free access and analysis of all the participants' individual data, the significance of the data obtained is beyond doubt. Availability of individual data increases the statistical power, allows for subgroup analyses and makes it possible to perform retrospective analysis of new parameters when obtaining new research data.

\section{BACKGROUND}

Scientific community, i.e., researchers, editors of medical journals, representatives of pharmaceutical companies, together with representatives of governmental control bodies, have been issuing statements concerning the need for increased research data transparency for many decades. Of particular concern have been the unregistered trials and unpublished research results, which demonstrate adverse effects of the intervention or no effects at all. Increasing competition forced the researchers to publish papers, reporting predominantly positive results, which gave rise 
to unfair assessment of the intervention, and gave a false impression of the medication or medical technology efficacy [2]. However, every researcher has to register the clinical trial to be conducted in accordance with the Declaration of Helsinki, which is considered by the WHO as an ethical, moral and scientific responsibility, and to report the research results $[3,4]$. That is why FDA changed the requirements for clinical trial registration in 1997. At that time the problems with trial registration transparency were identified, together with the lack of a single platform [5], which resulted in establishment of a single platform ClinicalTrials.gov in 2000 [6]. In 2005, mandatory trial registration as a prerequisite for publication was introduced by the International Committee of Medical Journal Editors (ICMJE) [7]; the WHO defined 20 basic items for trial registration since 2006, and launched the International Clinical Trials Registry Platform (ICTRP) in 2007 [8]. Later, in October 2008, the World Medical Association amended the Declaration of Helsinki by adding the principles for purported registration and public disclosure of the research results. Later the amendments were introduced in 2013: "Researchers are obliged to make the results of their research involving human subjects publicly available, they are responsible for completeness and accuracy of their research. All the parties should adhere to the adopted guidelines for ethical accountability. Negative and inconclusive or positive results should be published or disclosed in a different manner" [9]. Thus, obligation to disclose the results of all studies in a sincere and full manner was postulated. In the same year, 2013, the European Medicines Agency launched the new version of the European Union Drug Regulating Authorities Clinical Trials Database (EudraCT), containing information about protocols and results of clinical trials [10]. This register was largely consistent with Clinical Trials gov. A year later, Francis S. Collins, director of the National Institutes of Health $(\mathrm{NIH})$, raised the issue of the need for research transparency, timely correction of errors, and adverse events reporting, referring to the need for maximal use of the knowledge for the greatest benefit to human health, as well as to what society owed to each clinical trial participant [11]. The same association established the time limit of 12 months for publishing the results after the study completion in 2015 [12]. Thus, the rules on timely submission of reports were strengthened annually due to the quest for transparency and extended legal responsibility, as reflected in the final rule issued by U. S. Food and Drug Administration in 2016 [13], and Federal Policy for the Protection of Human Subjects revised in 2017 [14].

Currently, legislative and regulatory framework on biomedical ethics and human rights continues to improve on all continents involving the international community. There are some international initiatives helping to improve the clinical trial transparency: Ottawa Group [15], which proposed a consensus document on global registration of clinical trials, signed by the $\mathrm{WHO}$; Cochrane Community [16], providing accessible and appropriate information, supporting informed decision-making, based on systematic reviews and meta-analyses; UK Medical Research Council [17]; U. S. National Institutes of Health [18]; Institute of Medicine of the U. S. National Academy of Sciences [19]. Many pharmaceutical companies and medical publishing companies have also participated and continue to participate actively in the campaign. They redefined their policy in order to improve access to research data. Thus, the PLoS (Public Library of Science) journal was one of the first to request unrestricted access to data after publication of the article. Later the All
Trials campaign was launched All Trials [20], which brought together many publications and scientific communities, as well as Yale University Open Data Access web-site [21], ClinicalStudyDataRequest.com web-site [22], which brought together many pharmaceutical companies, provided unidentified access to data in accordance with the decision of a panel of independent experts with mandatory publishing of data sharing results in refereed journals, and worked with the motto: "Sharing clinical trial data: maximizing benefits, minimizing risk" [23]. Currently, the WHO, UK National Institute for Health Research, USA, European Commission, and editors of many medical journals adhere to this principle.

The Nordic Trial Alliance Working Group on Transparency and Registration has been forged in Europe under the pilot project, involving the Scandinavian countries. The Alliance has embarked on the development of the effective and optimal method for clinical trial registration, raising public awareness on the trials and trial results, and individual participant data depersonalization. Regulations have been established, recommended for consideration and adoption at the statute level by States, in which clinical trials are conducted as amended in accordance with the current legislation. These regulations allow for unification and harmonization of research quality standards, data protection in the era of globalization with preservation of research results transparency [24].

\section{CONCEPT OF TRANSPARENCY}

In today's world, clinical trial transparency entails several levels:

\section{Mandatory registration of clinical trials}

Primary (prospective) registration of the clinical trial on the generally accepted international platforms on a priority basis prior to inclusion of participants. Registration of interventional and non-interventional studies, as well as the studies of medical devices, is mandatory. In addition, principles of transparency also provide for retrospective registration. Commitment to registration may be traced through the increase in the number if registered trials. The annual number of registered clinical trials in 2004 accounted for 3,294 interventional trials, and in 2013 it was 23,384 [25]. In 2013, international register contained information about a total of 186,523 trials, and in 2021 this figure went up to 378,460 trials. (Fig., source: https:// clinicaltrials.gov/ct2/resources/trends).

The figure above illustrates the increase in the number of registered trials after the introduction of requirements for clinical trial registration by the International Committee of Medical Journal Editors (ICMJE, 2005) and Food and Drug Administration (FDA, 2007). Registration of trials contributes to effective knowledge sharing due to prevention of overlapping research, as well as the intervention futility and unexpected harm [29].

\section{Publishing the clinical trial results and submitting the report regardless of the study results}

WHO, World Medical Association (WMA), and European Medical Agency (EMA) request submission of the study results within 12 months after the date of the study completion, i.e. the final date of data acquisition aimed at measuring the initial result. Most of the clinical trial results become open to the public after being published in the peer-reviewed medical journal or on the web-sites where the clinical trials have 


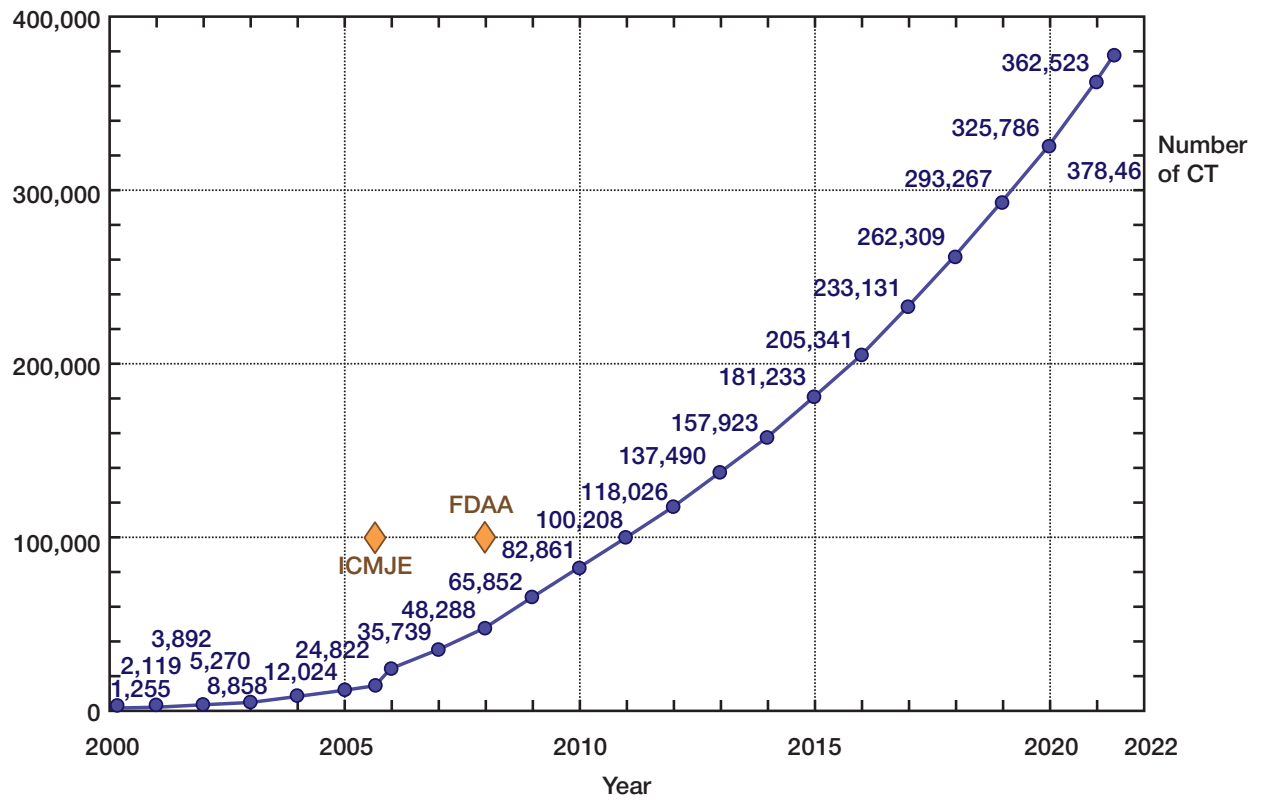

Fig. Dynamic changes in the number of registered CT

been registered. Detailed reports are prepared in accordance with the requirements of the International Conference on Harmonisation of Technical Requirements for Registration of Pharmaceuticals for Human Use (ICH-GCP) [26], and with the CONSORT Statement [27].

FDA has stated (final rule) that in the case of failure to comply with the requirements concerning the time limits for submission of data, penalties would be imposed in the amount of $\$ 12,000$ thousand per day of delay. Last year the study was published in the Lancet journal, where the authors assessed the average time of submitting the information by the researchers on the ClinicalTrials.gov web-site from March 2018 to September 2019: only $40 \%$ of reports were submitted in a timely manner (95\% Cl 39.4-42.2), the average delay of reporting after the date of the study completion was 424 days $(95 \% \mathrm{Cl} 412-$ 435), which exceeded the required time limit by 59 days [28]. Moreover, the authors noted, that industry sponsors reported in time, in contrast to state-owned companies and smaller sponsors. Unfortunately, despite the penalties and lawsuit, the compliance remains low. According to some authors, this is due to impossibility of reporting negative study results with limited funding, as well as to attempting to keep the data safe from competitors.

\section{Availability of depersonalized (anonymous) participants' data to the scientific community for further analysis.}

Clinical study reports are always more complete than publicly available data summaries, published on web-sites. However, such reports are most often available on request. Personal data of the participants are never included in the reports in deference to the personal data confidentiality. Currently, data depersonalization procedure is an extremely important issue, since only anonymized participants' personal data can be shared by the researchers and used for independent review of the clinical trial results and further systematic analysis. The participants' confidence that no re-identification is possible provides full compliance to ethical standards and principles of conducting clinical trials, protecting the interests of the study participant.
To summarize the main principles of the clinical trial transparency, it is worth noting that evidence-based medicine requires complete and thorough reporting, and timely disclosure of information would merely benefit all parties: clinicians, researchers, patients and study participants. This information allows clinicians to use alternative methods of treatment in patients, and contributes to better mutual understanding with the researchers. After gaining accurate insight into up-to-date evaluation of the issue, researchers can make more effective use of data for good planning and research taking into account all possible complications, pharmacoeconomic losses, and avoid the adverse events. The clinical trial participants have the right to know about the study results, to be given full access to the information about the study and all potential risks, and to understand their role and great personal contribution to healthcare promotion. Patients have the opportunity to learn about new technologies and medications, which provides an opportunity for selection of therapy, and increases public confidence in clinical trial data.

To overcome the existing problems with transparency of data, society and industry should understand that clinical trial data cannot be the property of the sponsor. These data are the property of the entire world community, serving to improve the quality of care provided. The system should be upgraded in order to avoid data entry duplication, simplify obtaining the reports for further analysis, ensure better protection of the study participants' personal data, and create a universal digital portal allowing for long-term storage of the data set and simultaneous use of the data set by global health community.

\section{CONCLUSION}

Research data transparency is the ongoing challenge and the only way to control safety and efficiency of therapy and vaccination, which is becoming increasingly important during the pandemic of the novel coronavirus infection. Moreover, this is one of the most effective means to motivate and improve vaccination coverage in order to create herd immunity. This would make it possible to prevent the further spread of infection and help the entire world community to return to a normal existence. 
1. Higgins JPT, Thomas J, Chandler J, Cumpston M, Li T, Page MJ, Welch VA (editors). Cochrane Handbook for Systematic Reviews of Interventions version 6.2 (updated February 2021). Cochrane, 2021. Available from www.training.cochrane.org/handbook.

2. Fanelli D. Do pressures to publish increase scientists' bias? An empirical support from US States Data. PLoS ONE. 2010; 5(4): e10271.

3. World Medical Association. WMA Declaration of Helsinki - Ethical Principles for Medical Research Involving Human Subjects. Last update: October 2013; wma net. Available from www.wma.net/ en/30publications/10policies/b3/.

4. World Health Organization. Trial Registration; International Clinical Trials Registry Platform (ICTRP). Last update: August 2014; who int. Available from www.who.int/ictrp/trial_reg/en/

5. Food and Drug Administration Modernization Act of 1997. Public Law 105-115; 105th Congress. Available from www.govinfo.gov/ content/pkg/STATUTE-111/pdf/STATUTE-111-Pg2296.pdf.

6. Press Release: National Institutes of Health Launches "ClinicalTrials. gov". Available from www.nlm.nih.gov/archive/20040831/news/ press_releases

7. International Committee of Medical Journal Editors. Registration of clinical trials. Available from www.icmje.org/recommendations/ browse/publishing-and-editorial-issues/clinical-trial-registration.html.

8. International Clinical Trials Registry Platform (ICTRP). Available from www.who.int/clinical-trials-registry-platform

9. Declaration of Helsinki Stakeholders Meeting in Washington, DC. WJM, 2013; 4(59):132-135. Available from www.wma.net/wpcontent/uploads/2016/11/wmj201304.pdf

10. European Medicines Agency launches a new version of EudraCT EMA/563462/2013. Available from www.ema.europa.eu/en/news/ european-medicines-agency-launches-new-version-eudract

11. $\mathrm{HHS}$ and $\mathrm{NIH}$ take steps to enhance transparency of clinical trial results. 2014. Available from www.nih.gov/news-events/newsreleases/hhs-nih-take-steps-enhance-transparency-clinical-trial-results

12. The National Cancer Institute Policy Ensuring Public Availability of Results from NCl-supported Clinical Trials. 2015. Available from www.grants.nih.gov/grants/guide/notice-files/NOT-CA-15-011.html

13. Clinical Trials Registration and Results Information Submission, 2016. Available from www.federalregister.gov/ documents/2016/09/21/2016-22129/clinical-trials-registrationand-results-information-submission.

14. Federal Policy for the Protection of Human Subjects, 2017. Available from www.federalregister.gov/documents/2017/01/19/2017-01058/ federal-policy-for-the-protection-of-human-subjects

15. Ottawa Group. Ottawa Statement on Trial Registration. Available from www. ottawagroup.ohri.ca.

16. A brief history of Cochrane. Higgins JPT, Thomas J, Chandler J, Cumpston M, Li T, Page MJ, Welch VA (editors). Cochrane Handbook for Systematic Reviews of Interventions version 6.2 (updated February 2021). Cochrane, 2021. Available from www. training.cochrane.org/handbook.

\section{Литература}

1. Higgins JPT, Thomas J, Chandler J, Cumpston M, Li T, Page MJ, Welch VA (editors). Cochrane Handbook for Systematic Reviews of Interventions version 6.2 (updated February 2021). Cochrane, 2021. Available from www.training.cochrane.org/handbook.

2. Fanelli D. Do pressures to publish increase scientists' bias? An empirical support from US States Data. PLoS ONE. 2010; 5(4): e10271.

3. World Medical Association. WMA Declaration of Helsinki - Ethical Principles for Medical Research Involving Human Subjects. Last update: October 2013; wma net. Available from www.wma.net/ en/30publications/10policies/b3/.

4. World Health Organization. Trial Registration; International Clinical Trials Registry Platform (ICTRP). Last update: August 2014; who int. Available from www.who.int/ictrp/trial_reg/en/
17. OECD Principles and Guidelines for Access to Research Data from Public Funding. Available fromhttps://www.oecd.org/sti/ inno/38500813.pdf

18. Final NIH Policy for Data Management and Sharing. Available from https://grants.nih.gov/grants/guide/notice-files/NOT-OD-21-013.html

19. Committee on Strategies for Responsible Sharing of Clinical Trial Data, Board on Health Sciences Policy, Institute of Medicine. Discussion Framework for Clinical Trial Data Sharing: Guiding Principles, Elements, and Activities. Washington, D.C.: The National Academies Press; 2014. Available from www.nap.edu/ openbook. php?record_id $=18610$

20. All Trials Campaign. What All Trials is calling for Last update: November 2014; Sense About Science. Available from www. alltrials.net/wp-content/uploads/2013/09/What-does-all-trialsregistered-and-reported-mean.pdf

21. Yale University Open Data Access (YODA) Project Procedures to Guide External Investigator Access to Clinical Trial Data Last Updated February 2019. Available from www.yoda.yale.edu/howrequest-data

22. Clinical study data request.com. Available from www. clinicalstudydatarequest.com

23. Committee on Strategies for Responsible Sharing of Clinical Trial Data, Board on Health Sciences Policy, Institute of Medicine. Sharing Clinical Trial Data: Maximizing Benefits, Minimizing Risk. Washington, D.C.: The National Academies Press; 2015. Available from www.nap.edu/catalog.php?record_id $=18998$

24. Transparency and Registration in Clinical Research in the Nordic Countries, 2015. Available from www.nta.nordforsk.org/projects/ nta_transparency_report.pdf.

25. Viergever RF, Li K. Trends in global clinical trial registration: an analysis of numbers of registered clinical trials in different parts of the world from 2004 to 2013. BMJ Open 2015;5: e008932. DOI: 10.1136/bmjopen-2015-008932

26. International Conference on Harmonization Guideline for International conference on harmonization of technical requirements for registration of pharmaceuticals for human use. Guideline for Good Clinical Practice E6 (R1). ICH Harmonized Tripartite Guideline. 10 June 1996. Available from www.ich.org/fileadmin/Public_Web_Site/ ICH_Products/Guidelines/Efficacy/E6/E6_R1_Guideline.pdf

27. The Consort Group. Consort statement. Last update: March 2010; www world psychiatric association org. Cited: 2009 Apr. 7. (7th Congress in Vienna, Italy) Available from http://www.consortstatement.org/

28. DeVito, Nicholas J; Bacon, Seb; Goldacre, Ben (2020). Compliance with legal requirement to report clinical trial results on ClinicalTrials. gov: a cohort study. The Lancet, S0140673619332209 -. DOI:10.1016/S0140-6736(19)33220-9

29. Al-Shahi SR, Beller E, Kagan J, Hemminki E, Phillips RS, Savulescu J, et al. Increasing value and reducing waste in biomedical research regulation and management. Lancet. 2014; 383(9912):176-185
5. Food and Drug Administration Modernization Act of 1997. Public Law 105-115; 105th Congress. Available from www.govinfo.gov/ content/pkg/STATUTE-111/pdf/STATUTE-111-Pg2296.pdf.

6. Press Release: National Institutes of Health Launches "ClinicalTrials. gov". Available from www.nlm.nih.gov/archive/20040831/news/ press_releases

7. International Committee of Medical Journal Editors. Registration of clinical trials. Available from www.icmje.org/recommendations/ browse/publishing-and-editorial-issues/clinical-trial-registration.html.

8. International Clinical Trials Registry Platform (ICTRP). Available from www.who.int/clinical-trials-registry-platform

9. Declaration of Helsinki Stakeholders Meeting in Washington, DC. WJM, 2013; 4(59):132-135. Available from www.wma.net/wpcontent/uploads/2016/11/wmj201304.pdf 
10. European Medicines Agency launches a new version of EudraCT EMA/563462/2013. Available from www.ema.europa.eu/en/news/ european-medicines-agency-launches-new-version-eudract

11. $\mathrm{HHS}$ and $\mathrm{NIH}$ take steps to enhance transparency of clinical trial results. 2014. Available from www.nih.gov/news-events/news releases/hhs-nih-take-steps-enhance-transparency-clinical-trialresults

12. The National Cancer Institute Policy Ensuring Public Availability of Results from NCl-supported Clinical Trials. 2015. Available from www.grants.nih.gov/grants/guide/notice-files/NOT-CA-15-011.htm

13. Clinical Trials Registration and Results Information Submission, 2016. Available from www.federalregister.gov/ documents/2016/09/21/2016-22129/clinical-trials-registrationand-results-information-submission.

14. Federal Policy for the Protection of Human Subjects, 2017. Available from www.federalregister.gov/ documents/2017/01/19/2017-01058/federal-policy-for-theprotection-of-human-subjects

15. Ottawa Group. Ottawa Statement on Trial Registration. Available from www. ottawagroup.ohri.ca.

16. A brief history of Cochrane. Higgins JPT, Thomas J, Chandler J, Cumpston M, Li T, Page MJ, Welch VA (editors). Cochrane Handbook for Systematic Reviews of Interventions version 6.2 (updated February 2021). Cochrane, 2021. Available from www. training.cochrane.org/handbook.

17. OECD Principles and Guidelines for Access to Research Data from Public Funding. Available fromhttps://www.oecd.org/sti/ inno/38500813.pdf

18. Final NIH Policy for Data Management and Sharing. Available from https://grants.nih.gov/grants/guide/notice-files/NOT-OD-21-013. html

19. Committee on Strategies for Responsible Sharing of Clinical Trial Data, Board on Health Sciences Policy, Institute of Medicine. Discussion Framework for Clinical Trial Data Sharing: Guiding Principles, Elements, and Activities. Washington, D.C.: The National Academies Press; 2014. Available from www.nap.edu/ openbook.php?record_id=18610

20. All Trials Campaign. What All Trials is calling for Last update: November 2014; Sense About Science. Available from www.
alltrials.net/wp-content/uploads/2013/09/What-does-all-trialsregistered-and-reported-mean.pdf

21. Yale University Open Data Access (YODA) Project Procedures to Guide External Investigator Access to Clinical Trial Data Last Updated February 2019. Available from www.yoda.yale.edu/howrequest-data

22. Clinical study data request.com. Available from www. clinicalstudydatarequest.com

23. Committee on Strategies for Responsible Sharing of Clinical Trial Data, Board on Health Sciences Policy, Institute of Medicine. Sharing Clinical Trial Data: Maximizing Benefits, Minimizing Risk. Washington, D.C.: The National Academies Press; 2015. Available from www.nap.edu/catalog.php?record_id=18998

24. Transparency and Registration in Clinical Research in the Nordic Countries, 2015. Available from www.nta.nordforsk.org/projects/ nta_transparency_report.pdf.

25. Viergever RF, Li K. Trends in global clinical trial registration: an analysis of numbers of registered clinical trials in different parts of the world from 2004 to 2013. BMJ Open 2015;5: e008932. DOI: 10.1136/bmjopen-2015-008932

26. International Conference on Harmonization Guideline for International conference on harmonization of technical requirements for registration of pharmaceuticals for human use. Guideline for Good Clinical Practice E6 (R1). ICH Harmonized Tripartite Guideline. 10 June 1996. Available from www.ich.org/ fileadmin/Public_Web_Site/ICH_Products/Guidelines/Efficacy/E6/ E6_R1_Guideline.pdf

27. The Consort Group. Consort statement. Last update: March 2010; www world psychiatric association org. Cited: 2009 Apr. 7. (7th Congress in Vienna, Italy) Available from http://www.consortstatement.org/

28. DeVito, Nicholas J; Bacon, Seb; Goldacre, Ben (2020). Compliance with legal requirement to report clinical trial results on ClinicalTrials. gov: a cohort study. The Lancet, S0140673619332209 -. DOI:10.1016/S0140-6736(19)33220-9

29. Al-Shahi SR, Beller E, Kagan J, Hemminki E, Phillips RS, Savulescu J, et al. Increasing value and reducing waste in biomedical research regulation and management. Lancet. 2014; 383(9912):176-185 